\title{
Tahrip Edilmiş Eğimli Arazilerde Teraslama ve Ağaçlandırma Çalışmalarının Toprak Özelliklerini İyileştirmedeki Rolü
}

\author{
Mehmet Özalp ${ }^{1, *}$, Ferit Dehşet ${ }^{2}$, Bülent Turgut ${ }^{1}$, Saim Yıldırımer ${ }^{1}$, Eren İnanlı ${ }^{3}$ \\ ${ }^{1}$ Artvin Çoruh Üniversitesi, Orman Fakültesi, Orman Mühendisliği Bölümü, 08000, Artvin. \\ ${ }^{2}$ Elazığ Orman Bölge Müdürlüğü, Van Orman İşletme Müdürlüğü, Van Orman İşletme Şefliği, 65000, Van. \\ ${ }^{3}$ Karabudak Tarım Hayvancılık A.Ş., Çankaya, 06400, Ankara.
}

\section{Özet}

Devlet Su İşleri tarafindan uygulanan Çoruh Barajlar Projesi kapsamında planlanan toplam 15 büyük barajdan biri olan Deriner Barajının inșası ve yapılan yol çalıșmaları sonucunda Çoruh Nehri Havzası'nda ciddi arazi tahribatları oluşmaktadır. Bu çalışmada, yol çalışmalar sonucunda tahrip olan alanlardaki erozyon kontrol ve ağaçlandırma uygulamalarında teraslama ve fidan dikimi çalışmalarının toprak özelliklerini iyileştirmede etkili olup olmadiğg incelenmiştir. Bu amaçla, teraslama yapılarak yalancı akasya ve sarıçam fidanları ile ağaçlandırılmış iki erozyon kontrol alanı ile müdahale görmemiş ormanlı alandan (kontrol) alınan toplam 45 toprak örneği üzerinde tekstür, $p H$, organik madde, toplam azot, toplam kireç ve elektrik iletkenliği analizleri yapılmıştır. Yapılan istatistikî değerlendirmeler sonucunda ağaçlandırma yapılan alanlardaki toprak özelliklerinde belirli bir seviyede iyileşme gerçekleştiği ama bu iyileşmenin doğal orman örtüsü altındaki toprak özellikleri ile klyaslandığında yeterli olmadı̆̆ belirlenmiştir. Örneğin, doğal orman alanında organik madde \%3.71 ve pH 7.69 olarak tespit edilmişken, aynı özellikler, sırası ile akasya parselinde \%1.13 ve 7.99, sarıçam sahasinda ise \%0.86 ve 7.93 olarak bulunmuştur.

\section{$\underline{\text { Anahtar Sözcükler }}$}

Arazi Tahribatı, Toprak Erozyonu, Erozyon Kontrol ve Ağaçlandırma Çalışmaları, Toprak Özelliklerinin İyileştirilmesi

\section{Role of Terracing and Reforestation Efforts on Improving Soil Properties in Degraded Steep Lands}

\begin{abstract}
Serious land degradation have been occurring during the building of new roads associated with the construction of Deriner Dam, one of 15 large dams planned by the General Directorate of State Hydraulic Affairs and implemented within the Coruh Dam Projects. In this study, whether terracing and planting of seedling efforts in degraded areas as a result of building new roads within erosion control and reforestation efforts have any effect on improving soil characteristics were investigated. In accordance with this purpose, parameters including soil texture, pH, organic matter, total nitrogen, total lime, and electrical conductivity were determined for 45 soil samples taken from three different areas; two of which were erosion control areas where terraces built and planted with acacia and yellow pine seedlings, along an undisturbed (control) area with natural forests. After evaluating statistical analyses run on the soils data, it was determined that the reforestation efforts have resulted in improvements of soil properties at some degree but when they are compared to the soils of the undisturbed natural forest, it is clear that the degree of improvement is not sufficient yet. For example, while the organic matter of $3.71 \%$ and $\mathrm{pH}$ of 7.69 were determined for the forest area, same parameters were found as $1.13 \%$ and 7.99 for the acacia and $0.86 \%$ and 7.93 for the yellow pine areas, respectively.
\end{abstract}

$\underline{\text { Keywords }}$

Land Degradation, Soil Erosion, Erosion Control and Reforestation Efforts, Improvement of Soil Properties

\section{Giriş}

Ülkelerin gelişmişlik derecesi ile doğal ekosistemlerin korunması veya tahrip edilmesi arasında doğru ilişki olduğu söylenebilir. Örneğin, gelişmekte olan/az gelişmiş ülkelerde bilinçsiz üretim veya tarıma dönüştürmeye bağlı ormansızlaşma (de la Paix vd. 2013), doğal alanlara yayılan yerleşim ve sanayileşme (Atmış vd. 2007; Zapata ve Robledabo 2014), tekniğine uygun yapılmayan orman veya karayolu inşaatları (Cerda 2007), kasitlı yangınlar (Cerda ve Lasanta 2005; Martin vd. 2012; Hanson vd. 2013) ile bilimsel temellere dayanmadan ve çevresel etkileri yeterince tartışılmadan izin verilen büyük baraj ve madencilik gibi yatırım projeleri şeklinde kendini gösteren insan kaynaklı etmenler nedeni ile başta orman ve mera alanları tahrip edilmeye devam ederken, gelișmekte olan ülkelerde ise bunun tersine daha çok koruma ve geliştirme programlarına (Rigueiro-Rodriguez vd. 2012; Rudel vd. 2010) ağırlık verilmektedir. 
Gelişmekte olan ülkeler arasında gösterilen Türkiye'de de özellikle orman vasfindaki alanlarda devam eden kentleşme ve sanayileşme girişimleri, buna bağlı olarak yapılan yeni yol inşaatları, ana nehir havzalarında planlanan yüzlerce sayıdaki büyük baraj ve HES yapımları, dereler üzerinde planlanan binlerce makro ve mikro HES projeleri, taş ocağı, mermer ve diğer metallerin işletilmesini hedefleyen madencilik faaliyetleri gibi müdahalelerin son y1llarda dramatik bir şekilde arttığı görülmektedir. Tüm bu müdahaleler, doğal olarak, özellikle ekolojik açıdan olumsuz sonuçları ve ciddi çevresel problemleri de beraberinde getirmektedir. Örneğin, son dönemlerde ülkemizin en önemli sorunlarından biri olan enerji açı̆̆ını kapatmak, içme ve tarımsal amaçlı su biriktirmek, sel kontrolü ve hidroelektrik enerjisi sağlamak gibi çeşitli amaçlarla büyük baraj ve HES projelerine öncelik verilmektedir. Dünya Barajlar Komitesi (WCD) verilerine göre, 1949 yılına kadar Dünya'da sadece 5000 civarında baraj varken, özellikle 1950'li yıllarla beraber hem artan nüfusa hem de büyüyen ülke ekonomilerine bağlı talep artışı neticesinde, Dünya'daki akarsuların yarısından fazlası üzerinde sayıları 45000'i geçen baraj inşa edilmiştir (WCD 2000). Ülkemizde de baraj yapımına yönelik yatırımlar 1950'li yıllardan sonra başlamıştır. 2007 itibarı ile Ülkemizde 600'e yakın baraj mevcuttur ve bunların yaklaşık 150'sinde ise aynı zamanda bir hidroelektrik santral (HES) kurulmuştur. Toplam hidroelektrik potansiyelinin \%36'sına karşılık gelen bu sayıya, inşaatları devam eden 36 adet HES ve uzun vadede yapılması planlanan 500'ün üzerinde HES ile beraber Türkiye'deki toplam HES sayısının uzun vadede 700'ü geçmesi planlanmaktadır (DSİ 2007). Baraj projelerinde, özellikle yerel ve ulusal ekonomiye katkı açısından üzerinde durulması gereken bir diğer önemli sorun ise Türkiye’nin \%90 gibi önemli kısmında değişik şiddet ve derecelerde görülen toprak erozyonudur (Balcı 1996; Özhan 2004). Diğer bir ifade ile barajların belirlenen sürelerde amaçlanan fonksiyonlarını sürdürmeleri ve özellikle HES'lerde elektrik enerjisi üretimi (barajların hizmet ömrü) o barajın su toplama havzasında oluşan toprak erozyonu ve bununla bağlantılı olan sedimantasyon olgusu ile doğrudan ilişkilidir.

$\mathrm{Bu}$ yatırım programlarından biri de Çoruh Nehri Havzası üzerinde planlanan 15 büyük baraj ve HES tesisini kapsayan ve DSİ tarafından yürütülen Çoruh Barajlar Projesidir (Özalp vd. 2009). 1990’lı yılların ortasında hayata geçirilen bu projede Çoruh Nehri'nin Artvin İli sınırları içerisinde akan ana kolu üzerinde mansaptan membaa doğru Muratlı, Borçka, Deriner, Artvin ve Yusufeli Baraj ve HES tesisleri olmak üzere 5 adet büyük baraj projesi bulunmaktadır ki bunlardan ilk üçü tamamlanarak işletme halindeyken son ikisi ise halen inşaat aşamasındadır. Ancak, bu projelerin inşaat aşamalarında meydana gelen ciddi doğa tahribatlarına, barajların su tutmaya başlaması ile havzanın özellikle vadi tabanında yer alan yerleşim yerleri ve dolayısı ile ulaşımın yapıldı̆̆ı yolların da yenilenmesi çalışmaları sonucunda ortaya çıkan arazi bozulmaları da eklenince çevre tahribatının boyutu oldukça arttığı tamamlanan baraj örnekleri ile açık bir şekilde bilinmektedir (Toker 2010; Sever 2005).

Çoruh Nehri Havzası'nda yeryüzü şekillerinin dağlık ve eğimli olmasından dolayı, baraj yapımı çalışmalarının doğaya vermiş olduğu zararın en önemli kısmını önceleri Çoruh Nehri ve yan kollarına paralel olarak yapılan ulaşım yollarının yüksek kotlara çıkarılması sırasında ortaya çıkan kazı malzemesinin şevlerden aşağıya gelişigüzel bir şekilde atılması oluşturmaktadır (Özalp vd. 2009; Toker 2010; Dehşet 2011; Yıldırımer 2015). Oysa yasal mevzuatlar (örn: Hafriyat Yönetmeliği, Kıyı Kanunu, vb.) normal koşullarda ve yapılan iş sözleşmeleri gereği bu yolların yapımı sırasında ortaya çıkan kazı malzemesinin uygun alanlarda depo edilmesi gerekmektedir. Ancak, ortaya çıkan kazının yüksek eğimli şevlerden gelişigüzel atılması ile hem o şevlerdeki bitki örtüsüne zarar vermekte hem de arazi tahribatı ve toprak erozyonu oluşmasına neden olmaktadır. Eğimle beraber yol genişliği ve dolgu hacmi arttıkça çevreye verilen zarar da büyümektedir. Uygun tekniklerin uygulanmadığı bu çalışmalara denetimsizlik, plansız çalışmalar ve duyarsızlık da eklenince Vadide yürütülen baraj ve yol inşaatlarının doğal kaynaklar üzerindeki olumsuz etkileri daha da ciddi boyutlara ulaşmaktadır (Toker 2010; Dehşet 2011).

1990'ların sonlarında yoğunlaşan büyük baraj ve yeni yol inşaatları nedeni ile tahrip olan araziler üzerinde 2000'li yılların başından itibaren Artvin İl Çevre ve Orman Müdürlüğü bünyesindeki Ağaçlandırma ve Erozyon Kontrol Şube Müdürlüğü tarafından erozyon kontrol ve ağaçlandırma çalışmaları başlatılmıştır. Ancak, yapılan bu çalışmaların zarar görmüş arazilerdeki toprak erozyonunu önlemede ve bu alanlardaki toprak özelliklerini iyileştirmede başarılı olup olmadığı konularında yapılan bilimsel çalışmalar oldukça sınırlı sayıdadır.

Bu çalışmada, Artvin'e yaklaşık 10 km uzaklıktaki Salkımlı Köyü civarında Deriner Barajı nedeni ile yenilenen karayolu yapım çalışmalarından dolayı bozulan alanlarda yürütülen erozyon kontrol ve ağaçlandırma çalışmalarının tahrip edilen arazilerdeki toprak özellikleri üzerinde iyileştirici bir rolü olup olmadığı araştırılmıştır.

\section{Materyal ve Metot}

\section{1. Çalışma Alanı}

Ülkemizde bulunan 25 ana havzadan biri olan Çoruh Nehri Havzası, Bayburt ilindeki Mescit Dağlarından başlayıp Gürcistan'ın Batum ilinden Karadeniz'e dökülen Çoruh Nehri ve bu nehri besleyen çok sayıda yan koldan oluşmaktadır. DSİ verilerine göre yılda 5.8 milyon $\mathrm{m}^{3}$ sediment taşımaktadır (bu özelliği ile Türkiye'de en çok toprağın taşındığı havzaların başında gelmektedir) ve yıllık ortalama 6.3 Milyar $\mathrm{m}^{3}$ akış hacmine sahiptir. Nehrin toplam uzunluğu $431 \mathrm{~km}$ olup, 410 km'si ülkemiz sınırları içerisinde, 21 km'lik kısmı ise Gürcistan sınırları içerisinde yer almakta ve bu açıdan "sınır aşan havza" veya "uluslararası havza" özelliğindedir.

DSİ Genel Müdürlüğü, Çoruh Nehri Havzası'nın enerji olanaklarının ortaya konulması için yapılan araştırmalar sonucunda oluşturduğu rapor ile 1969 yılında Çoruh Nehri ve yan kolları üzerinde baraj projelerini gündeme almıştır. 
Bu tarihten itibaren baraj yerlerindeki temel (zemin) araştırmalarına başlanarak elde edilen sonuçlara göre 1979 yılında Çoruh Havzası Mastır Planı Raporu Mühendislik Hizmetleri işi ihale edilmiş ve 1982 yılında alanla ilgili bir Mastır Plan hazırlamıştır (Sever 2005; DSİ 2007). Çoruh Nehri'nin ana ve yan kollarında 1954 y1lında başlayan ve 2007 yılına kadar aralıklarla devam eden etüt çalışmaları sonucunda Çoruh Nehri ana ve yan kollarında 15 adeti büyük baraj ve 22 adet regülatör tipi (yan kollar üzerinde su depo etmeyen dere tipi HES tesisi) olmak üzere toplam 37 adet baraj ve HES projesi planlanmıştır. Bu projelerin toplam kurulu gücü $3133 \mathrm{MW}$ ve yıllık ortalama enerjisi ise 10.55 milyar kWh olarak hesaplanmıştır (Saraç ve Eciroğlu 2008).

Günümüzde Çoruh Barajlar Projesi olarak yürütülen bu yatırım programı kapsamında şu ana kadar Artvin il sınırları içerisinde 2004 yılında Muratlı, 2006 yılında Borçka ve 2012 yılında ise Deriner Barajları tamamlanmış, Artvin ve Yusufeli Barajlarının ise inşaatları devam etmekte ve sırası ile 2016 ve 2018 yıllarında bitirilmeleri planlanmaktadır (Şekil 1).

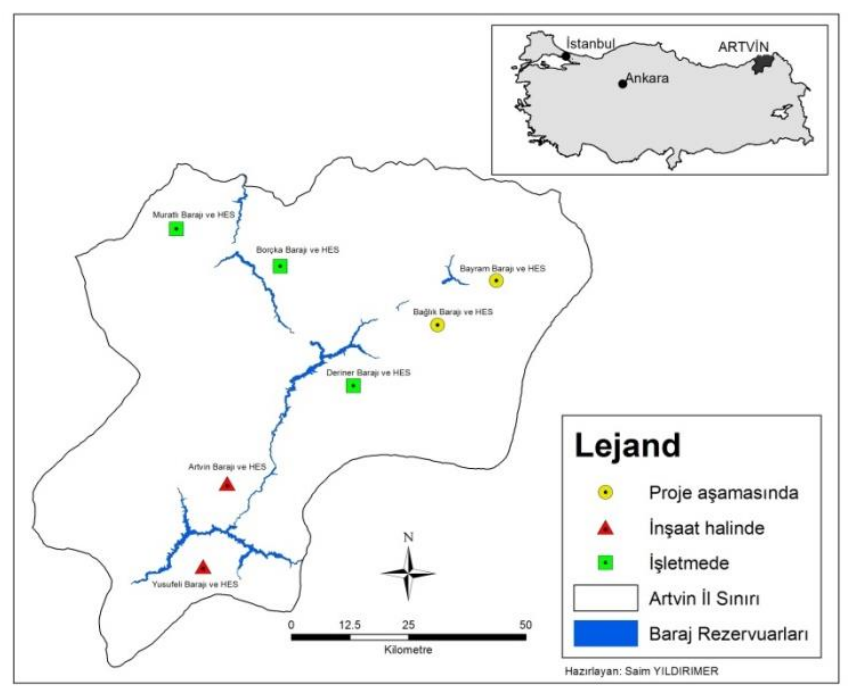

Şekil 1: Çoruh Nehri Havzasında ana ve yan kollar üzerinde planlanan büyük baraj projelerinin yerlerini gösteren harita

Araştırma sahası Çoruh Nehri Havzası'nın Artvin merkeze bağlı Salkımlı Köyü sınırları içerisinde yer almakta olup

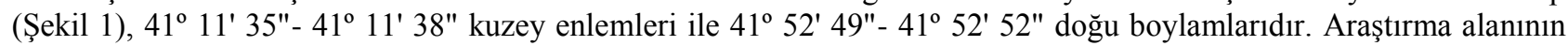
denizden yüksekliği ortalama 635 m'dir.

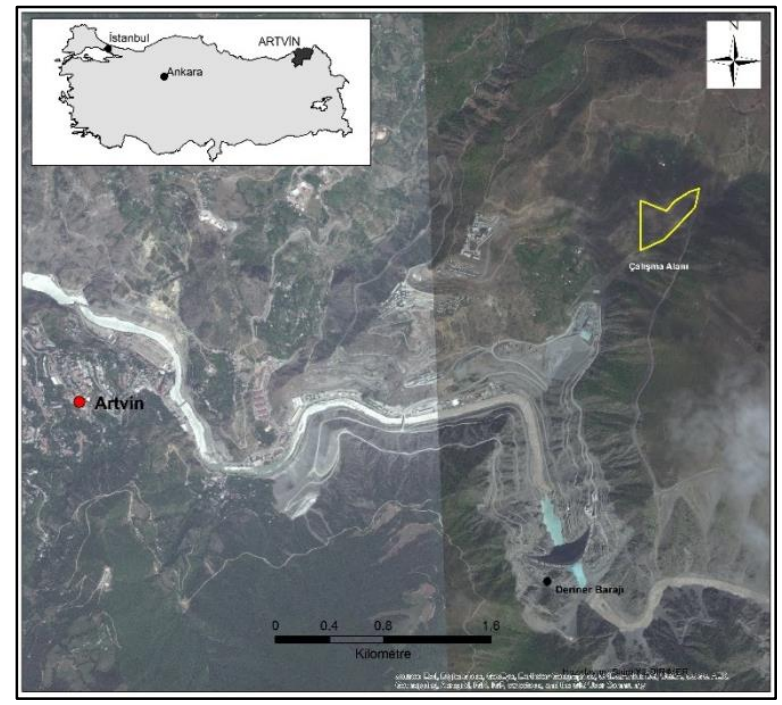

Şekil 2: Deriner Barajı ve bağlantıı olarak yapılan yol inşası nedeniyle tahrip edilen arazi üzerinde seçilen araştırma sahasının konumu

Jeolojik olarak bakıldığında Artvin, Kuzey Anadolu orojenik kuşağı dâhilinde yer almaktadır. Bölgenin en eski arazisini meydana getiren metamorfik seri, Çoruh Nehri'nin aşağı kesimlerinden başlayarak Sirya (Zeytinlik) üzerinden kuzeydoğuya doğru uzanmaktadır (Gattinger 1962). Artvin ve yöresinin en büyük jeolojik ünitesi olan üst kretase volkanik ve volkano-sedimanter serileri asit ve nötr lavlarla bunlara ait anglomera ve tüflerden, bunlar arasında ince 
yataklar halinde yer alan ve çoğunluğu kırmızı renkli olan marn ve kalker tabakalarından meydana gelmektedir. Lav serisi içerisinde dasit, andezit, kiparit, kuvarsporfirler bulunmaktadır (Gattinger 1962, Ketin 1949, Ketin 1954).

Çalışma alanı, granit anakaya üzerinde oluşmuş kahverengi orman toprağı ile temsil edilmekte ve yamaç toprağından (kolüvyal malzeme) oluşmaktadır. Çalışma alanı ve Çoruh Nehri Havzası genelinde bulunan kahverengi orman toprakları büyük çoğunlukla çok dik veya sarp eğimlerde yer almaktadır ki araştırma sahamızın ortalama eğimi $\% 60$ 'ın üzerinde bulunmuştur. Bu toprakların \%60'dan fazlasının derinliği $20 \mathrm{~cm}$ 'den daha az, \%31'ininki 20-50 cm'dir. Eğimin çoğunlukla fazla olması ve doğal örtünün tahribi sonucu bu toprakların \%90'dan fazlası şiddetli veya çok şiddetli erozyona maruzdur. Toprakların \%34’ü \%10'un üzerinde taşl1lığa sahiptir. Çoruh Havzası'ndaki kahverengi orman topraklarının kullanım kabiliyeti bakımından \%90.4'ü VII., \%6.4'ü VI. ve \%3.1'i IV. sinıftır. Toprakların \%0.1'i de III. sınıfa girmektedir (TSGM 1984).

Artvin ve çevresi, iklim özellikleri itibariyle de bir geçiş bölgesi karakteri taşımaktadır ve genel olarak Karadeniz kıyı (oseyanik), Karadeniz ardı (yarı karasal) ve Doğu Anadolu (karasal) iklim kuşaklarına sahiptir (Yüksek ve Ölmez 2002; URL-1 2011). Artvin Meteoroloji İstasyonu'nun 33 ylllık (1975-2007) gözlem verilerine göre Artvin'in yıllık ortalama sıcaklığı $11.9^{\circ} \mathrm{C}$, yıllık ortalama yağı̧̧ miktarı ise $723.6 \mathrm{~mm}$ 'dir. Yıllık ortalama yağış miktarının en düşük olduğu ay $28.9 \mathrm{~mm}$ ile Ağustos ayı, ortalama yağış miktarının en yüksek olduğu ay ise $98.3 \mathrm{~mm}$ ile Ocak ayıdır (Tablo $1)$.

Tablo 1: Artvin Meteoroloji istasyonu'nun 1975-2007 (33 yıllık) yılları arasındaki bazı iklim verileri.

\begin{tabular}{|c|c|c|c|c|c|c|c|c|c|c|c|c|c|}
\hline İklim & \multicolumn{12}{|c|}{ AYLAR } & YILLIK \\
\hline Elemanları & I & II & III & IV & $\mathrm{V}$ & VI & VII & VIII & IX & $\mathrm{X}$ & XI & XII & \\
\hline $\begin{array}{c}\text { Ort. Max. } \\
\text { Sicakl1k }{ }^{\circ} \mathrm{C}\end{array}$ & 5.9 & 7.6 & 12.0 & 17.7 & 21.4 & 23.7 & 25.4 & 25.8 & 23.6 & 19.2 & 12.7 & 7.3 & 16.9 \\
\hline $\begin{array}{l}\text { Ort. Min. } \\
\text { Sicaklık }{ }^{\circ} \mathrm{C}\end{array}$ & -0.8 & -0.4 & 2.3 & 6.8 & 10.6 & 13.7 & 16.5 & 16.8 & 13.7 & 9.8 & 4.9 & 1.0 & 7.9 \\
\hline $\begin{array}{l}\text { Ort. Sicaklık } \\
{ }^{\circ} \mathrm{C}\end{array}$ & 2.4 & 3.3 & 6.7 & 11.8 & 15.5 & 18.4 & 20.5 & 20.7 & 17.8 & 13.7 & 8.5 & 4.0 & 11.9 \\
\hline $\begin{array}{l}\text { Ort. Yağış } \\
\quad(\mathrm{mm})\end{array}$ & 98.3 & 73.3 & 59.3 & 58.9 & 53.1 & 49.2 & 31.1 & 28.9 & 32.0 & 64.1 & 80.4 & 95.0 & 723.6 \\
\hline
\end{tabular}

Artvin, bitki coğrafyası ve flora bölgesi açısından Euro-Siberian (Avrupa Sibirya) alanının Colchis (Kolşik) kesimi içinde yer almaktadır. Daha çok yapraklı türlerden oluşan bir orman vejetasyonu egemen olup, yükseltiye bağlı olarak topluma iğne yapraklı taksonlar da katılmaktadır (Anşin 1983). Alanda mevcut olarak meşe, karaağaç ve ardıc türleri bulunmaktadır. Araştırma alanın bulunduğu yörede yol yapım çalışmaları yapılmadan önce mevcut olan meşcere tipi BM-T (Bozuk Meşe-Taşlık) olarak sınıflandırılmıştır. Ancak, yukarıda da belirtildiği gibi yol yapım çalışmaları ile tahrip olan bu arazilerde 2000'li yılların başından itibaren belirli aralıklarla erozyon kontrolü ve ağaçlandırma çalışmaları başlatılmış ve bu kapsamda alana çıplak köklü yapraklı türlerden yalancı akasya, ceviz, ıhlamur, badem, iğde ve tüplü iğne yapraklı türlerden sarıçam ve sedir türleri dikilmiştir. Bu çalışmanın gerçekleştiği parsellerde ise dikim yolu ile getirilen yalancı akasya ve sarıçam türleri ile ekim yolu ile otlandırma amaçlı kullanılan korunga türleri bulunmaktadır.

Yalancı akasya ülkemizde 1916 yılından beri daha çok yol kenarı ağaçlandırmaları amacıyla yetiştirilmektedir. Genellikle ülkemiz ormancıları tarafından kurak mıntıka ağaçlandırmaları ve fakir toprakları ıslah etmek için uygun bir tür olarak bilinmekle birlikte, esasında bu türün iyi gelişmesi için özellikle vejetasyon mevsiminde rutubetli derin ve gevşek topraklar istemektedir. Dünyada üçüncü hızlı gelişen yapraklı türdür. Gevşek ve derin topraklarda, nisbi rutubetin veya toprak neminin iyi olduğu, toprak hazırlığının tam alanda, bakımların zamanında yapıldığı yerlerde yılda hektarda $10 \mathrm{~m}^{3}$ ü geçmemektedir (Atay 1985; Yaltırık 1991; Kızmaz 1998). Son yıllarda ağaçlandırmalarda sıkça kullanılan türlerden biride yalancı akasyadır. Yalancı akasya kanaatkâr bir tür olması, gençlikte hızlı büyümesi, çiçeklerinin arıcılıkta faydalı olması, kökleri ile azot bağlaması ve odunun yüksek kalori değerine sahip, sert ve dayanıklı olması özellikleri ile ağaçlandırmalarda tercih edilen türlerden biridir. Ayrıca ülkemizde daha fazla süre çiçekte kalan yalancı akasya genotipleri belirlenerek bunların arıcıllğın yoğun olduğu bölgelerdeki ağaçlandırmalarda kullanılması gerektiği bildirilmektedir (Tüfekçioğlu vd. 2008).

Sarıçam sistematikte Açıktohumluların (Gymnospermae) Coniferae sınıfı, Pinaceae familyası, Pinus cinsinin Eupyts (pinestr.) seksiyonuna dâhil bir tür olarak verilmektedir (Yaltırı 1993). Yetişme ortamlarına göre 10-40 m kadar boylanan narin ve silindirik gövdeli, sivri tepeli ve ince dallı, ya da dolgun gövdeli yayvan tepeli ve kalın dallı bir herdem yeşil ağaçtır. Bazen fakir topraklarda ve kayalıklarda, arktik bölgelerde çalı halinde, bodur biçimde bulunur (Şekil 14). Karadeniz Bölgesi'nde Sürmene dolaylarında (Çamburnu) deniz kıyısına kadar inen sarıçam, Artvin, Rize çevresinde ladin ile karışık orman kurarak 2100 m’ye çıkar. Zigana dağlarında, Gümüşhane ve Giresun dolaylarında 
100 - 2440 m arasında saf ya da karışık, Amasya, Sinop, Kastamonu dolaylarında, Bolu yöresinde saf ya da göknar ve kayınla karışık durumda bulunur. Karadeniz etkisinin hissedildiği Karadeniz Dağlarının güney yamaçlarında ve Çoruh Vadisinde 200 m’ye iner (Giray 1994). Dikey yayılış itibariyle en alçak 200 m'de (Borçka - Otingo Deresi güney yamaçlarında), en yüksek 2700 m’de (Ziyarettepe'de huşla birlikte) bulunmaktadır (Atay 1987; Giray 1994).

\section{2. Örnekleme Deseni ve Yapılan Analizler}

Bu araştırmada, Artvin'de Deriner Barajı'nın inşaatı nedeni ile kullanılamaz hale gelen yol ağının yukarı kotlara çıkarılması sırasında tahrip edilen arazilerden alınan toprak örnekleri üzerinde yapılan bazı hidro-fiziksel analiz sonuçları, Artvin Orman Bölge Müdürlüğü'nden alınan meşcere haritaları ile sahada yapılan erozyon kontrol ve ağaçlandırma çalışmalarına ait veriler kullanılmış ve irdelenmiştir. Araştırma alanı toplam üç farklı sahadan oluşmaktadır:

1. Yalancı Akasya Parseli: Tahrip edilmiş ve 2004 yılında yalancı akasya ile ağaçlandırılmış alan,

2. Sarıçam Parseli: Tahrip edilmiş ve 2005 yılında ibreli türlerle (sedir, sarıçam) ile ağaçlandırılmış alan

3. Orman Parseli: Tahrip görmemiş (doğal) alan (kontrol parseli) olarak tespit edilmiştir.

Yalancı akasya ve sarıçam parselleri belirlenirken, bu parsellerin erozyon kontrol amaçlı yapılan teraslardan 5 tanesini içermesi sağlandı. Böylece bu parsellerin her biri toplam 5 adet teras ve 5 adet de teras aralığından (Şekil 3) meydana gelmiş oldu. Toprak örneklemesi de, her bir teras ve teras aralığından 3'er adet olmak üzere planlandığından $\{(5+5)$ x 3$\}$ her bir parselden toplam 30 toprak örneği alınmış oldu. Orman (kontrol) içerinden alınan parselden (tahrip edilmemiş, doğal) ise bu alanda herhangi bir teraslama çalışması olmadığı için sadece 15 adet toprak örneği alındı.

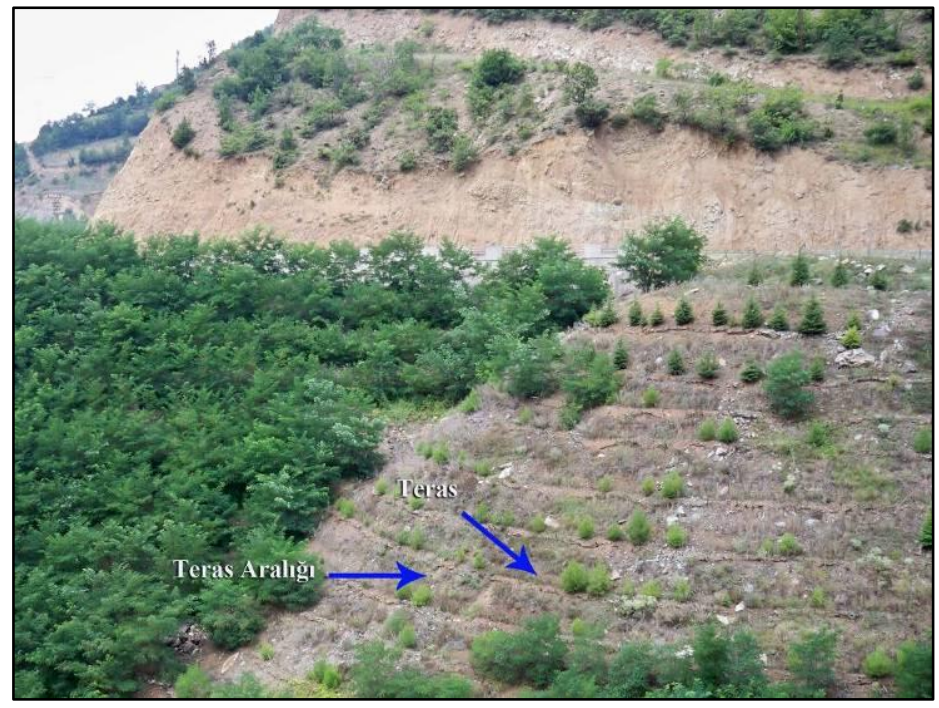

Şekil 3: Erozyon kontrolü ve ağaçlandırma çalışmalarının yapıldığı alandaki teras ve teras aralığının görüntüsü.

Alınan toplam 45 adet doğal yapısı bozulmuş poşet örnekleri laboratuvarda kurutma tavalarına koyularak hava kurusu hale gelene kadar kurutulduktan sonra porselen havanlarda dövülerek 2 mm'lik (kalın) ve 0.5 mm'lik (ince) eleklerden geçirilip numaralanmış kese kâğıtlarına doldurularak analize hazır hale getirildi. Toprak örneklerinin tekstür tayini Bouyoucos' un hidrometre yöntemi ve tekstür üçgeni yardımıyla belirlenmiştir. Toprak pH'ını belirlemek için, 20 gr hava kurusu ince toprak üzerine $25 \mathrm{ml}$ saf su ilave edildikten sonra bir gece bekletildikten sonra $\mathrm{pH}$ metre ile ölçümler yapılmıştır (Irmak 1954; Gülçur 1974). Organik madde miktarının tayini, 0.2 mm'lik elekten geçirilen 0.5 gr'lık örnekler üzerinde Walkley-Black'ın ıslak yakma yöntemine göre yapılmıştır (Kaçar 1996; Karagül 1994). Toprakta toplam azot miktarı Walkley-Black'1n 1slak yakma yöntemine göre hesaplanan organik maddenin \%20'si olarak belirlenmiştir. Toplam kireç $(\mathrm{CaCO} 3)$ tayini ise $0.5 \mathrm{~mm}$ 'lik elekten geçirilen 0.5 gr toprak örneği içine $1 / 3 \mathrm{HCI}$ çözeltisi bulunan kalsimetre tüpü daldırıldıktan sonra seyreltik hidroklorik asitle Scheibler Kalsimetresinde işleme tabi tutulup karbonatlardan çıkan CO2 gazı kapalı bir cam boruda tutularak hacmi ölçülmüş ve bu hacimden toprağın karbonat miktarı hesaplanmıştır (Gülçur 1974; Kaçar 1996). Toprakta Elektrik İletkenliği için 2 mm'lik elekten geçmiş yaklaşık 100 gr'llk toprak plastik kaplara konulmuş, saf su ile yavaş yavaş karıştırılarak saturasyon haline getirilmiştir. Daha sonra ağzı kapatılarak bir gece bekletilmiş ve ertesi gün vakum setinde süzülmüştür. Süzülen örnekler tüplerden alınarak 25 cc'lik beherlere sırası ile konulmuş, alınan örnekler kondaktivite aletinde okunarak, kondüktümetrik yönteme göre hesaplanmıştır (Gülçur 1974; Eruz 1979).

Araştırma sonuçları, tesadüf blokları deneme desenine göre değerlendirilmiştir. Sarıçam dikili alan, yalancı akasya dikili alan ve orman alanı blokları oluşturmuştur. Arazi kullanım durumları bakımından incelenen parametreler arasındaki farklılığın belirlenebilmesi için varyans analizi kullanılmıştır. Ayrıca gruplar arasındaki farklılığın 
karşılaştırılması için ise LSD çoklu karşılaştırma testinden yararlanılmıştır. İstatistikî analizler JMP paket programı ile yapılmıştır.

\section{Bulgular ve Tartışma}

\subsection{Teras Aralıkları ile Kontrol (Orman) Parselinin Toprak Özellikleri Bakımından Karşılaştırılması}

$\mathrm{Bu}$ araştırmada öncelikle yalancı akasya ve sarıçam ağaçlandırma parsellerinin teras aralıklarından alınan 15'er toprak örneğine ait analiz sonuçlarının, kontrol sahası olarak seçilen ve ağırlıklı olarak meşe ve ardıç türlerinden oluşarak baltalık olarak işletilen orman parseli ile karşılaştırılması yapılmıştır. Aşağıda, her üç deneme alanı toprak özellikleri bazında değerlendirilmiştir.

Kum İçeriği (\%): Üç farklı deneme parselindeki teras aralarından alınan toprak örneklerinin analizi ile elde edilen sonuçların ortalamaları kullanılarak yapılan varyans analizinde teras aralarının kum içerikleri bakımından farklılık gösterdiği ve bunun da istatistikî anlamda önemli olduğu tespit edilmiştir $(p<0.01)$. Yapılan çoklu karşılaştırma testi sonuçlarına göre ise en yüksek kum içeriği Orman (\%65.33) ve Akasya (\%63.69) parsellerinde bulunmuş, Sarıçam alanlarındaki teras araları ise en düşük oran olan \%59.93 ile temsil edilmiştir (Şekil 4).



Şekil 4: Araştırma sahasındaki orman, akasya ve sarıçam bloklarındaki teras aralarından alınan üst topraktaki kum miktarı değişimi.

Toz İçeriği (\%): Toprakların toz içerikleri istatistikî anlamda farklı bulunmuş $(\mathrm{p}<0.01)$ ve buna bağlı olarak yapılan çoklu karşılaştırma testinde en yüksek toz içeriği orman topraklarında tespit edilmiştir (\%13.55). Bunu sırası ile sarıçam (\%13.00) ve yalancı akasya parsellerindeki teras araları (\%8.69) takip etmiştir (Şekil 5). Orman ve sarıçam bloklarındaki teras araları aynı grupta yer almıştır (LSD: 1.95).

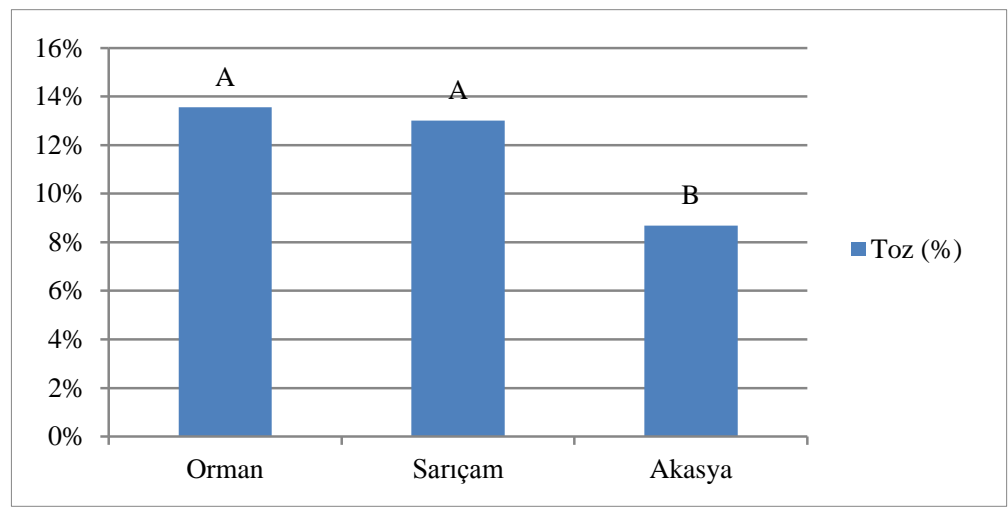

Şekil 5: Araştırma sahasındaki orman, sarıçam ve akasya bloklarındaki teras aralarından alınan üst topraktaki toz miktarı değişimi.

Kil İçeriği (\%): Her bir deneme parselinin teras aralarından alınan toprak örneklerinin analizi ile elde edilen sonuçların ortalamaları kullanılarak yapılan varyans analizinde teras aralarının kil içerikleri bakımından istatistikî anlamda birbirinden önemli derecede farklı olduğu tespit edilmiştir $(\mathrm{p}<0.01)$. Çoklu karşılaştırma testi sonuçlarına göre ise en yüksek kil içeriklerinin yalancı akasya (\%27.62) ve sarıçam alanlarındaki teras aralarından (\%27.07) elde edildiği, en düşük miktarın ise kontrol (orman) sahasında (\%21.12) olduğu bulunmuştur (Şekil 6). Bu nedenle, yalanc1 akasya ve sarıçam bloklarındaki teras araları aynı grupta yer almıştır (LSD: 2.73). 




Şekil 6: Akasya, sarıçam ve orman bloklarındaki teraslardan alınan üst topraktaki kil miktarı değişimi.

Toprak Reaksiyonu (pH), (1/2.5 H2O): Farklı bloklardaki teras aralarından alınan toprak örneklerinin analizi ile elde edilen sonuçların ortalamaları kullanılarak yapılan varyans analizinde teras aralarının $\mathrm{pH}$ değerleri bakımından bloklar arasındaki farklılığın istatistikî anlamda önemli olduğu tespit edilmiştir $(\mathrm{p}<0.01)$. Çoklu karşılaştırma testine tabi tutulan bu farklılıklar sonucunda en yüksek pH değeri yalancı akasya ile ağaçlandırılan alandaki topraklarda elde edilmiştir (7.99), bunu sırası ile sarıçam teras araları (7.93) ve orman parseli (7.69) takip etmiştir (Şekil 7). Yalancı akasya ve sarıçam bloklarındaki teras araları aynı grupta yer almıştır (LSD:0.08).

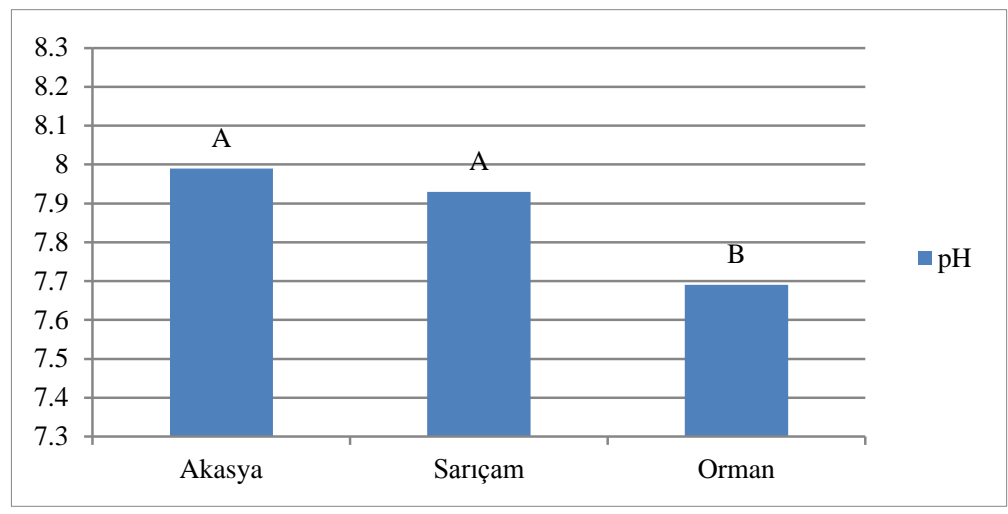

Şekil 7: Akasya, sarıçam ve orman bloklarındaki teras aralarından alınan üst topraktaki pH değişimi.

Toplam Kireç (\%): Yapılan varyans analizinde teras aralarının kireç içerikleri bakımından deneme sahaları arasında istatistikî anlamda önemli farklılıklar olduğu tespit edilmiştir $(p<0.01)$. Yapılan çoklu karşılaştırma testi sonuçlarına göre ise en yüksek kireç içeriğinin yalancı akasya (\%7.35) sahasındaki topraklarda, daha sonra sarıçam bloğundaki teras aralarında (\%3.85) ve en düşük miktarın ise orman alanındaki (\%1.34) toprak örneklerinde bulunduğu ortaya çıkmıştır (LSD:0.76) (Şekil 8).

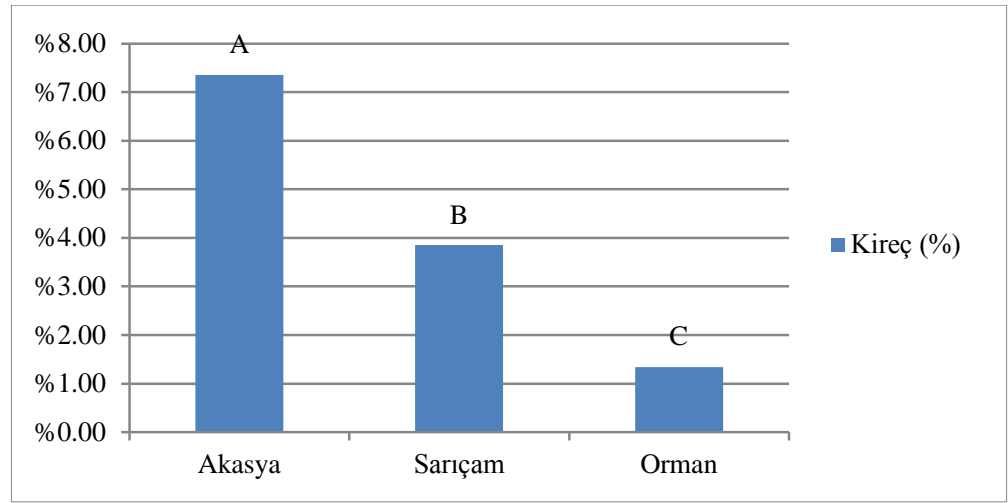

Şekil 8: Akasya, sarıçam ve orman bloklarındaki teras aralarından alınan üst topraktaki toplam kireç miktarı değişimi. 
Organik Madde (\%): Organik madde miktarının belirlenmesi için teras aralarından alınan toprak örneklerinin analizi ile elde edilen sonuçların ortalamaları kullanılarak yapılan varyans analizinde, teras aralarının organik madde içerikleri bakımından deneme sahaları arasında farklılıklar gösterdiği ve bu farklılıkların istatistikî anlamda önemli olduğu tespit edilmiştir $(\mathrm{p}<0.01)$. Araştırma sahasından alınan toprak örneklerinin analizleri sonucu elde edilen verilerle yapılan çoklu karşılaştırma testi sonuçlarına göre; en yüksek organik madde içeriği ormandan alınan toprak örneklerinde tespit edilmiştir (\%3.71), bunu sırası ile yalancı akasya (\%1.13) ve sarıçam teras araları (\%0.86) takip etmiştir (Şekil 9) (LSD:0.63) ve ortalamaların gruplandırılmasında ise yalancı akasya ve sarıçam deneme alanlarından elde edilen organik madde miktarının aynı grupta yer aldığı görülmüştür.

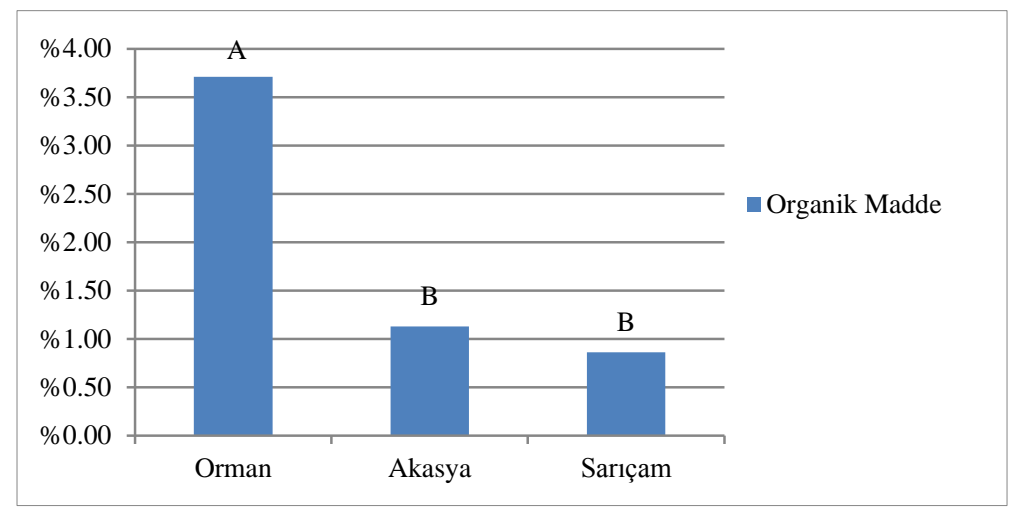

Şekil 9: Araştırma sahasındaki orman, akasya ve sarıçam bloklarındaki teras aralarından alınan üst topraktaki organik madde miktarındaki değişim.

Toplam Azot (N), (T-N) (\%): Yapılan varyans analizinde teras aralarının toplam azot içerikleri bakımından deneme parselleri arasındaki istatistikî anlamda önemli farklılıklar gösterdiği tespit edilmiştir $(\mathrm{p}<0.01)$. Araştırma sahasından alınan toprak örneklerinin analizleri sonucu elde edilen verilerle yapılan çoklu karşılaştırma testi sonuçlarına göre ise en yüksek toplam azot içeriği orman bloğundaki teras aralarından alınan topraklardan elde edilmiştir (\%0.19), bunu sırası ile yalancı akasya bloğundaki teras araları (\%0.06) ve sarıçam bloğundaki teras araları (\%0.04) takip etmiştir (Şekil 10) (LSD:0.03). Buna göre, yalancı akasya ve sarıçam ağaçlandırma sahalarındaki teras aralıkları aynı grupta yer almıştır.

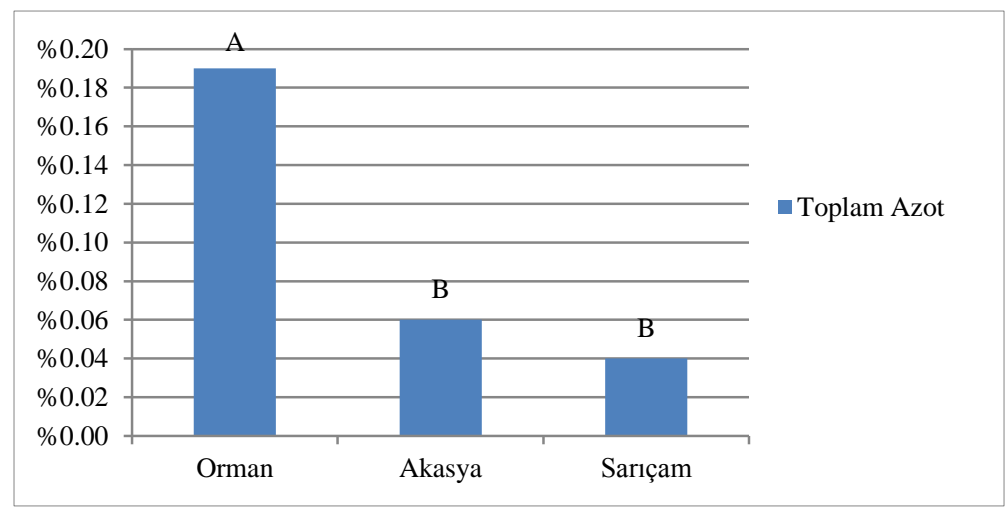

Şekil 10: Araştırma sahasındaki orman, akasya ve sarıçam bloklarındaki teras aralarından alınan üst topraktaki toplam azot miktarındaki değişim.

Elektrik İletkenliği (E.C.), (dS.m-1): Her bir parselden alınan toprak örneklerinin analizi ile elde edilen sonuçların ortalamaları kullanılarak yapılan varyans analizinde teras aralarının E.C. bakımından istatistikî anlamda birbirinden önemli derecede farklı olduğu tespit edilmiştir $(\mathrm{p}<0.01)$. Önemli derecede farklı bulunan bu veriler çoklu karşılaştırma testine tabi tutulmuş ve en yüksek E.C. oranının ormandan alınan toprak örneklerinde olduğu tespit edilmiştir (0.44). Bunu sırası ile yalancı akasya (0.29) ve sarıçam teras aralarındaki topraklar (0.26) takip etmiştir (Şekil 11) (LSD:0.05). 


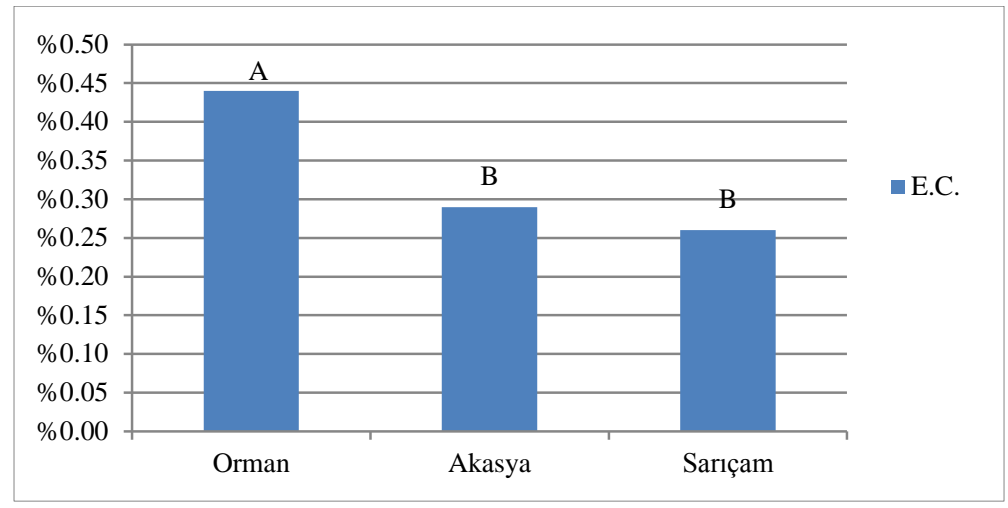

Şekil 11: Araştırma sahasındaki orman, akasya ve sarıçam bloklarındaki teras aralarından alınan üst topraktaki E.C değişimi.

\subsection{Teraslamanın Toprak Özellikleri Üzerine Etkileri}

Yukarıda belirtildiği üzere çalışmamızı oluşturan üç sahadan ikisi üzerinde erozyon kontrol amaçlı teraslar yapılmış ve yalancı akasya veya sarıçam fidanları kullanılarak ağaçlandırılmıştır. Bilindiği üzere teraslamanın arazinin eğimini düşürücü, toprak nemini arttırıcı ve toprağın organik madde miktarını arttırıcı etkileri bulunmaktadır (Balcı 1996; Ürgenç 1998; Özhan 2004). Bu nedenle, bu iki sahadaki toprak özelliklerinin terasların inşasından ve fidan dikiminden bu yana iyileşme gösterip göstermediği hem teraslardan hem de doğal orman alanından alınan toprak örneklerinin analiz sonuçları karşılaştırılarak irdelenmiş ve istatiksel sonuçlar aşağıda her bir toprak analizi bazında sunulmuştur.

Kum İçeriği (\%): Yapılan varyans analizinde kum içerikleri bakımından üç saha arasında farklılıklar olduğu ve bu farklılıkların istatistikî anlamda önemli olduğu tespit edilmiştir $(\mathrm{p}<0.01)$. Buna göre; araştırma sahasından alınan toprak örneklerinin analizleri sonucu elde edilen verilerle yapılan çoklu karşılaştırma testi sonuçlarına göre; en yüksek kum içeriği doğal ormanlık alandan elde edilmiştir (\%65.33). Bunu sırası ile akasya sahasındaki teraslar (\%64.38) ve sarıçam bloğundaki teraslar (\%60.62) takip etmiştir (Şekil 12). Orman alanı ile akasya sahalarındaki teraslarda sarıçam sahasındaki teraslara oranla önemli seviyede daha fazla kum miktarı olduğu tespit edilmiştir (LSD:2.60).

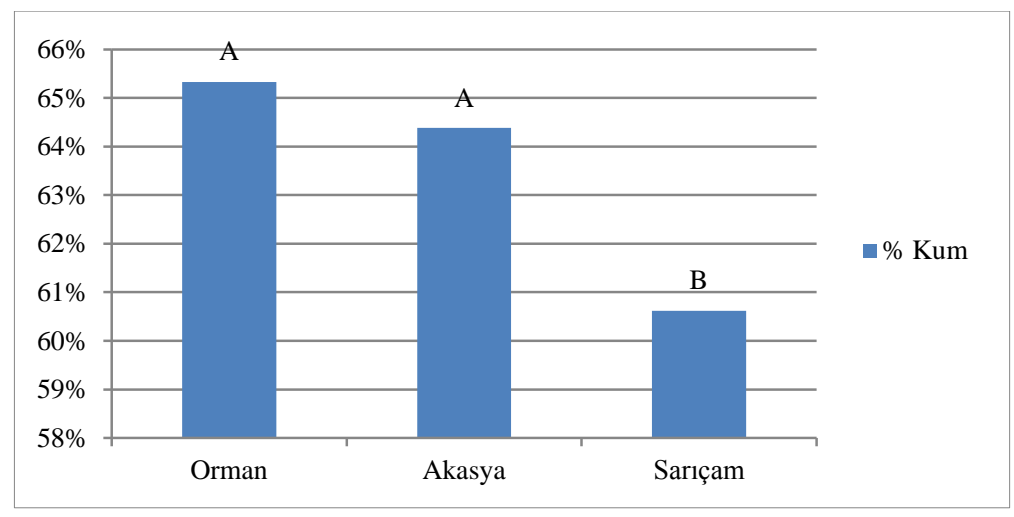

Şekil 12: Araştırma sahasındaki orman, akasya ve sarıçam bloklarındaki teraslardan alınan üst topraktaki kum miktarı değişimi.

Toz İçeriği (\%): Alınan toprak örneklerinin analizleri sonucunda üç sahanın topraklarının toz içerikleri bakımından istatistikî anlamda birbirinden önemli derecede farklı olduğu tespit edilmiştir $(p<0.01)$ ve yapılan çoklu karşılaştırma testi sonuçlarına göre en yüksek toz içeriği ormanda elde edilmişken (\%13.55), bunu sırası ile sarıçam ağaçlandırma sahasındaki teraslar $(\% 12.17)$ ve yalancı akasya sahasındaki teraslar (\%8.69) takip etmiştir (Şekil 13). Orman ve sarıçam sahalarındaki toz içerikleri akasya sahasındakilere nazaran önemli seviyede yüksek bulunmuş ve dolayısı ile aynı grupta yer almışlardır (LSD: 2.26). 


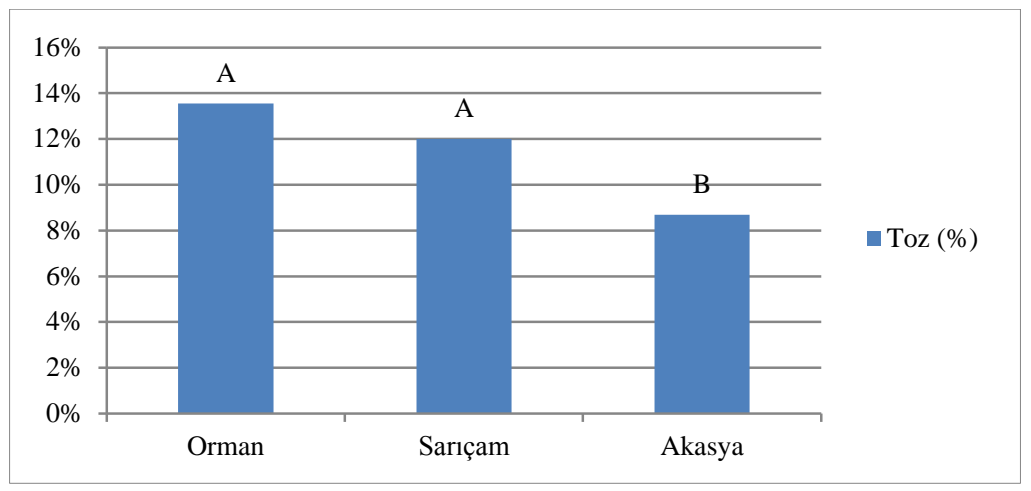

Şekil 13: Orman, Sarıçam ve Akasya bloklarındaki teraslardan alınan üst topraktaki toz miktarı değişimi.

Kil İçeriği (\%): Üç sahadaki toprakların kil içerikleri bakımından da istatistikî anlamda birbirinden önemli derecede farklı olduğu tespit edilmiştir $(p<0.01)$. Çoklu karşılaştırma testi sonuçlarına göre en yüksek kil içeriği sarıçam sahasındaki teraslardan elde edilmiştir (\%27.21), bunu sırası ile yalancı akasya sahasındaki teraslar (\%26.93) ve orman alanından alınan topraklar (\%21.12) takip etmiştir (Şekil 14). Yalancı akasya ve sarıçam sahalarındaki terasların toprakları aynı grupta yer almıştır (LSD: 2.55).

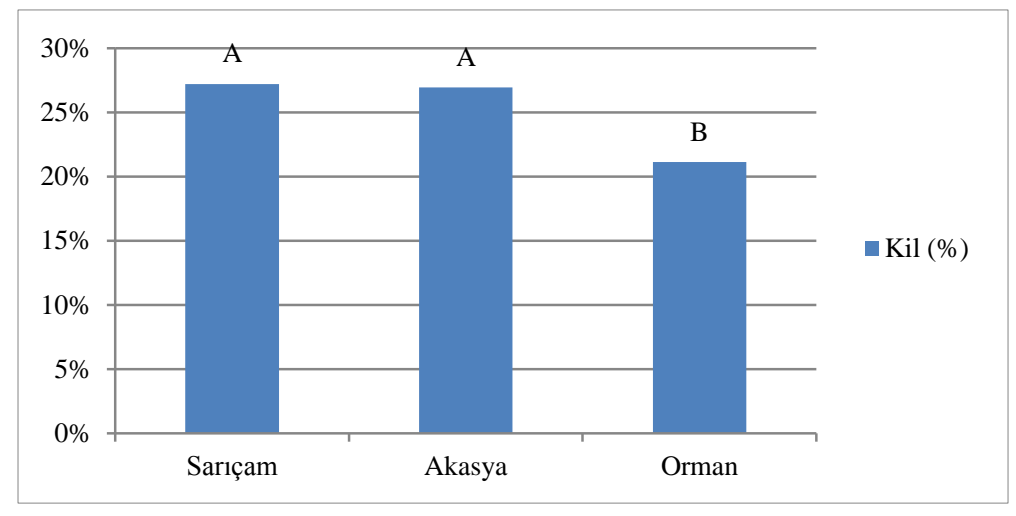

Şekil 14: Sarıçam, Akasya ve Orman bloklarındaki teraslardan alınan üst topraktaki kil miktarı değişimi.

Toprak Reaksiyonu (pH), (1/2.5 H2O): Yapılan varyans analizinde terasların $\mathrm{pH}$ değerleri bakımından sahalar arasında istatistikî anlamda önemli farklılıklar olduğu tespit edilmiştir $(\mathrm{p}<0.01)$. Yapılan çoklu karşılaştırma testi sonuçlarına göre ise en yüksek $\mathrm{pH}$ değerlerinin akasya ve sarıçam sahalarındaki teraslardan elde edildiği (7.94) aynı grupta yer aldığı (LSD:0.11), bunu orman alanının (7.69) takip ettiği görülmüştür (Şekil 15).

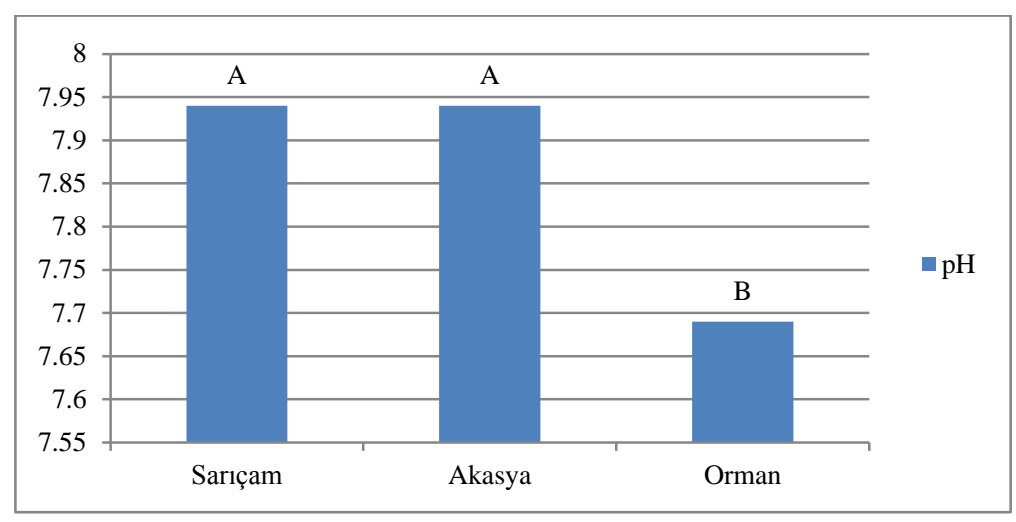

Şekil 15: Sarıçam, Akasya ve Orman bloklarındaki teraslardan alınan üst topraktaki pH değişimi.

Toplam Kireç (\%): Teraslardaki toprakların toplam kireç içerikleri bakımından her üç irdelenen sahanın da istatistikî anlamda birbirinden önemli derecede farklı olduğu tespit edilmiştir $(p<0.01)$. Çoklu karşılaştırma testine tabi tutulan ortalama kireç içerikleri içerisinde en yüksek kireç içeriği yalancı akasya sahasındaki teraslardan elde edilmiştir (\%7.39). Bunu sırası ile sarıçam (\%3.90) ve orman alanları (\%1.34) takip etmiştir (Şekil 16) (LSD:0.71). 


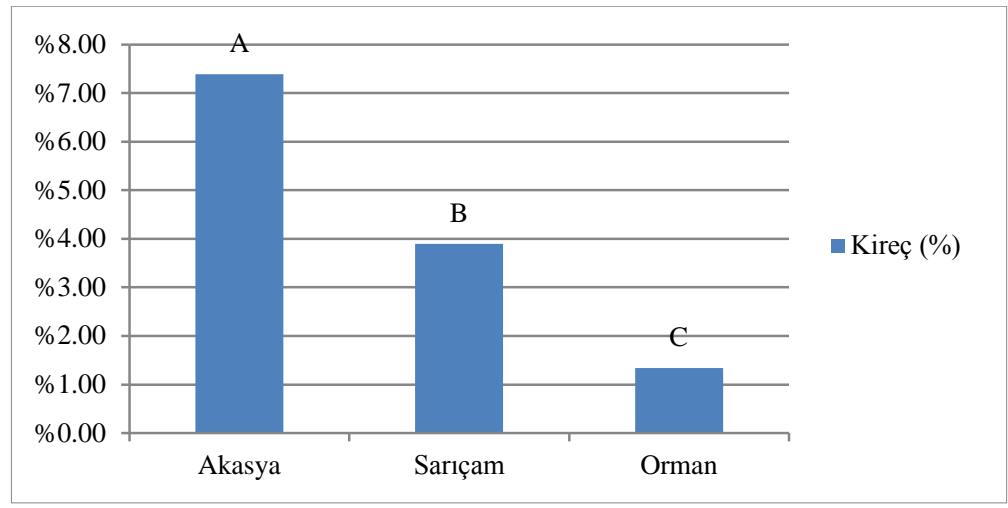

Şekil 16: Akasya, Sarıçam ve Orman bloklarındaki teraslardan alınan üst topraktaki toplam kireç miktarı değişimi.

Organik Madde (\%): Organik madde miktarının, her bir sahadaki terastan alınan toprak örneklerinin analizi ile elde edilen sonuçların ortalamaları kullanılarak yapılan varyans analizinde istatistikî anlamda birbirinden önemli derecede farklı olduğu tespit edilmiştir $(\mathrm{p}<0.01)$. Yapılan çoklu karşılaştırma testi sonuçlarına göre en yüksek organik madde içeriği kontrol sahası olan orman alanından elde edilmiştir (\%3.71) ve bunu sırası ile yalancı akasya (\%0.88) ve sarıçam alanındaki teraslar (\%0.84) takip etmiştir (Şekil 17) (LSD:0.59).

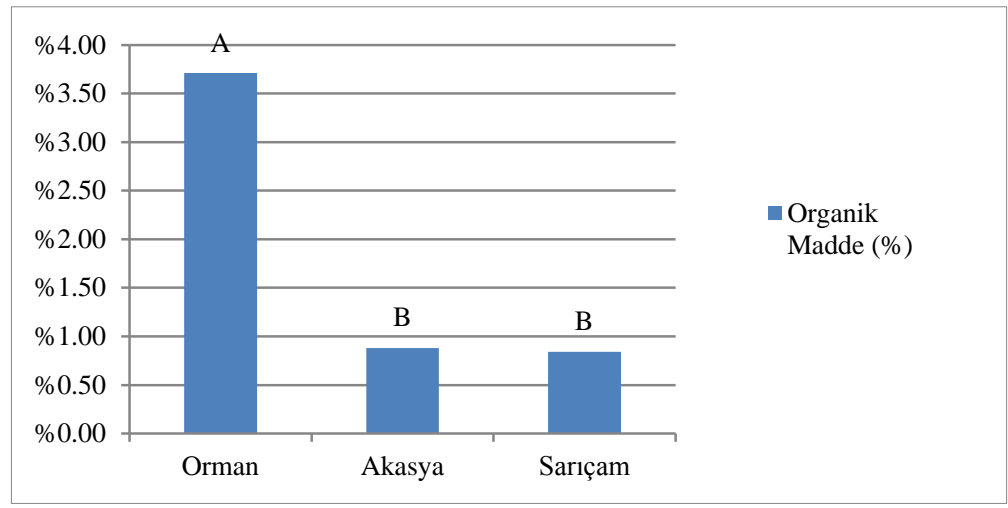

Şekil 17: Orman, Akasya ve Sarıçam bloklarındaki teraslardan alınan üst topraktaki organik madde miktarındaki
değişim.

Toplam Azot (N), (T-N) (\%): Yapılan varyans analizinde terasların toplam azot içerikleri bakımından üç deneme alanı arasındaki farklılığın istatistikî anlamda önemli olduğu tespit edilmiştir $(p<0.01)$ ve yalancı akasya ve sarıçam alanlarındaki teraslar aynı grupta yer almıştır. Önemli derecede farklı bulunan bu veriler çoklu karşılaştırma testine tabi tutulmuş ve en yüksek toplam azot içeriği kontrol amaçlı tespit edilen orman alanından elde edilmiştir (\%0.19), bunu sırası ile yalancı akasya bloğundaki teraslar $(\% 0.05)$ ve sarıçam bloğundaki teraslar (\%0.04) takip etmiştir (Şekil 18) (LSD:0.03).

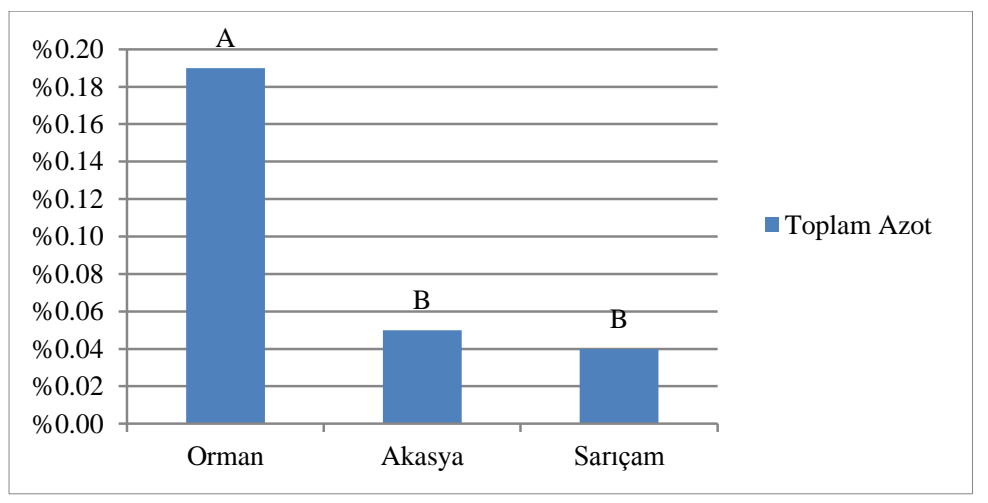

Şekil 18. Araştırma sahasındaki Orman, Akasya ve Sarıçam bloklarındaki teraslardan alınan üst topraktaki toplam azot miktarındaki değişim. 
Elektrik İletkenliği (E.C.), (dS.m-1): Teraslardan alınan toprakların E.C. bakımından sahalar arasında farklılıklar gösterdiği ve bu farklılığın istatistikî anlamda önemli olduğu tespit edilmiştir $(p<0.01)$. Çoklu karşılaştırma testi sonuçlarına göre ise en yüksek E.C. miktarı ormandaki topraklardan elde edilmiştir (0.44) ve bu fark ile diğer iki sahadan ayrılmıştır. Bunu, Akasya (0.29) ve Sarıçam deneme alanlarındaki teraslar (0.26) takip etmiştir (Şekil 19) (LSD:0.05).

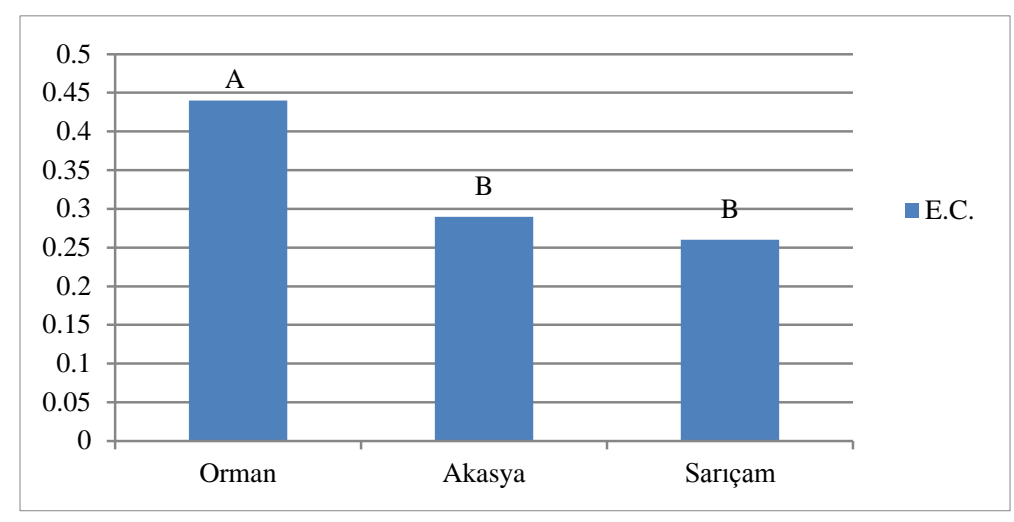

Şekil 19: Araştırma sahasındaki Orman, Akasya ve Sarıçam bloklarındaki teraslardan alınan üst topraktaki E.C. değişimi.

\section{Tartışma}

Toprak analiz sonuçlarının karşılaştırıldığı bulgular kısmından da açıkça görüleceğgi üzere araştırmada kullanılan üç farklı parsel (akasya ve sarıçam ağaçlandırma sahaları ile doğal orman örtüsü) arasında hem teraslar hem de teras aralarından alınan toprak özelliklerinin birbiri ile paralellik gösterdiği görülmektedir. Diğer bir ifade ile teraslamanın toprağı iyileştirmede henüz yeterince etkili olmadığı ve dolayısı ile teras aralarındaki toprak özellikleri ile oldukça benzer sonuçlar verdiği söylenebilir. Bu nedenle, tartışma bölümünde hem teraslar hem de teraslar arası toprak özelliklerinin sonuçlarının yapılan analiz bazında aşağıda beraber değerlendirilmesi uygun görülmüştür.

Kum, Kil ve Toz İçeriği: Bulgular kısmında da belirtildiği gibi en fazla kum içeriği orman parselinden alınan toprak örneklerinde tespit edilmiş, bunu yalancı akasya ve sarıçam parsellerindeki terasların toprağı takip etmiştir ki bu sonucun ana nedenlerinden biri olarak doğal orman örtüsünün bulunduğu alanın sahip olduğu yüksek eğime ve dolayısı ile artan yüzeysel akış neticesinde meydana gelen toprak yıkanması gösterilebilir. Yüzeysel akışla meydana gelen bu tür yıkanma olaylarında genellikle daha küçük tane çaplı toz ve kilin toprağın alt horizonlarına taşındığı bir gerçektir (Kantarc1 2000). Buna karşılık, ağaçlandırılan parsellerde ise yaklaşık olarak orman sahası ile aynı derecede olan yüksek eğim teraslar sayesinde kırılmıştır ve bunun da yüzeysel akışın hızını azalttığı ve böylelikle tutulan kil minerallerinin miktarını arttırdığı düşünülmektedir. Ayrıca terasların inşası çalışmalarında teraslar açılırken ortaya çıkan ve genellikle verimli topraklardan oluşan malzeme aslında fidanlar dikildikten sonra tekrar kullanılması gerekirken, bu tekniğe uyulmadığından belki de kum içeriği yüksek olan yüzey toprakları doğrudan şevlerden aşağ atılarak kum içeriğinin azalmasına neden olmuş olabilir. Buna ilave olarak, bu işlemden dolayı alt tabakada olan kil minerallerinin de açığa çıkarak kil miktarını arttırdığı düşünülmektedir.

Benzer şekilde Artvin Çoruh Havzası Deriner Barajı yol şevi ve geçici yerleşim yeri çevre ağaçlandırılmasında kullanılan farklı türlerin altındaki toprakların bazı özelliklerinin doğal ve açık alanların toprak özellikleriyle karşılaştırılması ile ilgili bir çalışmada da (Sarıyıldız 2008), doğal meşe ile açık alandaki toprakların teraslama yapılmış ve akasya ile ağaçlandırılmış alandaki topraklardan daha yüksek miktarda kum içerdikleri tespit edilmiştir. Kum miktarları bakımından alanlar arasında önemli farklılıklar bulunmamakla beraber, kil miktarları bakımından, açık alanlarla karşılaştırıldığında doğal ve yalancı akasya ağaçlandırması yapılan alanların daha yüksek kil miktarına sahip olduğu görülmektedir.

Aynı şekilde Artvin Merkez Seyitler Köyünde erozyon kontrol amaçlı yapılan ağaçlandırma çalışmasının bazı toprak özelliklerine etkisinin araştırıldığı çalışmada da (Yüksek vd. 2010), kil minerallerinin özellikle eğimin etkisiyle zaman içerisinde yıkanarak ortamdan uzaklaşması ya da alt tabakalara taşınması dolayısıyla kaba materyalin ve kum miktarının artmasının toprak oluşumunda ya da erozyon alanlarında meydana gelen bir süreç olduğu; özellikle yüzeysel erozyon sonucu kil miktarının azalmasının kum miktarı ve kaba materyal oranını artırabildiği ve kil içeriğini düşürebildiği bulunmuştur.

pH (Toprak Reaksiyonu): Araştırma sahasından alınan toprak örneklerinin analizi sonucunda pH değerinin yalancı akasya ve sarıçam teras toprağında en yüksek, doğal orman alanındaki topraklarda ise düşük olduğu tespit edilmiştir. Çalışmamızda yalancı akasya ve sarıçam teras topraklarında tespit edilen yüksek kil miktarı pH değerindeki bu artışın nedenlerinden biri olarak gösterilebilir. Genel olarak toprakta kil miktarı arttıkça değiştirilebilir katyonların miktarı da artmaktadır. Değiştirilebilir katyonların artması ise toprağın aşırı derecede asitleşmesini önlemektedir ki bu olaya toprağın tampon etkisi denilmektedir ve aşırı $\mathrm{pH}$ değişikliklerine karşı toprağın gösterdiği reaksiyon olarak da 
tanımlanır (Kantarcı 2000). Çünkü bilinen bir gerçek vardır ki bir toprakta kil içeriğinin fazla olması beraberinde yüksek katyon tutma kapasitesini de getirir. Böylece topraktaki kil içeriğinin artışına bağlı olarak bazik iyonlar artmış ve beraberinde $\mathrm{pH}$ yükselmiş olabilir. Ayrıca, bitki örtüsü faaliyetlerinin uzun süreli ve fazla olduğu alanlarda toprağın organik maddece zengin olması ve toprakta yaşanan fiziksel ve kimyasal olaylar sonucu toprağın asitlik derecesinin artmış olabileceği de özellikle ormanlık alandaki pH değerinin akasya ve sarıçam ağaçlandırma alanına göre düşük olmasina neden olarak gösterebilir.

Benzer şekilde Artvin Çoruh Havzası Deriner Barajı yol şevi ve geçici yerleşim yeri çevre ağaçlandırılmasında kullanılan farklı türlerin altındaki toprakların bazı özelliklerinin doğal ve açık alanların toprak özellikleriyle karşılaştırılması ile ilgili bir çalışmada da (Sarıyıldız 2008) alanlarının pH değerleri incelendiğinde, açık alanlardaki toprakların $\mathrm{pH}$ değerlerinin ağaçlandırma yapılan alanlardan daha yüksek olduğu görülmektedir. Buna karşılık, aynı çalışmada, değişik türler arasında ise pH değeri bakımından önemli farklılıklar tespit edilmemiştir. Aynı çalışmada, hem doğal alanlarda hem de ağaçlandırma yapıldıktan sonra yaklaşık 10 yıl geçmesine rağmen alan topraklarındaki pH değerindeki azalma, yine de istenen düzeyde olmadığı belirtilmiştir ve bu durumun başlıca nedeni olarak, alanların oldukça eğimli olması nedeniyle organik maddenin yeterli miktarda tutulamaması ve alandan yağış suları ve yüksek eğim nedeniyle uzaklaştırılması gösterilmiştir. Organik madde azlığı, organik maddeye bağımlı olarak yaşayan mikroorganizmaların sayısını, çeşitliliğini ve aktifliğini etkilediği bir gerçektir (Balc1 1996; Özhan 2004). Bununla beraber, yalancı akasyanın toprakların organik madde miktarını diğer iki farklı türe göre daha fazla arttırıcı yönde rol oynadığı belirtilmektedir (Yüksek vd. 2010; Sarıyıldız 2008).

Kireç: Araştırma sahasında teraslardan alınan toprak örneklerinin analizi sonucunda kireç değeri en fazla yalancı akasya sahasında, daha sonra sarıçam ve orman parsellerinden alınan topraklarda görülmüştür. Orman alanındaki topraklarda kireç miktarının az olması bu alandaki doğal toprak yapısı üzerinde meydana gelen yıkanmaya bağlanabilir (Kantarc1 2000). Tahrip görmüş diğer iki sahada kirecin yüksek çıkması ise yapılan yol çalışmaları ile ortaya çıkan ve şevlerden gelişi güzel olarak aşağı atılan kazı malzemesi içerisinde kireçli malzemenin de olması ile açıklanabilir. Diğer bir ifade ile yüzeyin altında henüz topaklaşmamış ve kireç miktarı yüksek anakaya materyalinin yüzeye çıkarılıp buradaki toprakla karıştırılmış olması tahrip edilmiş akasya ve sarıçam alanlarında kirecin yüksek çıkmasına neden olmuş olabilir.

Bunun yanında, akasya parselindeki toprağın kireç açısından sarıçama göre daha fazla çıkması ise akasya fidanlarının sarıçam fidanlarına göre daha hızlı gelişerek oluşturduğu yüksek kapalılık nedeni ile burada kireç yıkanmasının daha az olabileceği ihtimaline bağlanabilir. Ayrıca, teraslar hazırlanırken üst toprağın sıyrılarak tahrip edilmesi ve kısmen de olsa alt katmandaki kirecin açığa çıkması da bir diğer neden olarak düşünülmektedir.

Organik Madde: Toprağın organik maddesi toprakta yetişen bitkiler ile toprak içinde yaşayan canlıların artıklarından oluşur. Ormanda toprağın organik maddesinin önemli bir kısmı ağaçların yaprakları, meyve ve tohumları, bunlara ait kozalak, vd. organlar, kabuklar ve dallardır.

Araştırma sahasından alınan toprak örneklerinin analizi sonucunda organik madde miktarı en fazla orman topraklarında, daha sonra yalancı akasya ve sarıçam teraslarındaki topraklarda tespit edilmiştir. Bu durumun ilk ve en açık nedenlerinden biri olarak orman parselindeki bitki örtüsünün ve topraktaki organizma faaliyetinin diğer iki sahaya nazaran daha fazla korunmuş olması gösterilebilir. Yalanıı akasyadaki teras toprağının sarıçam teras toprağına göre organik maddece zengin olmasının sebebi olarak da; yalancı akasyanın sarıçam fidanlarına oranla daha hızlı büyümesi ve yalancı akasya bloğunda yapılan korunga dikimi ile yapılan otlandırmanın sarıçam bloğundakine göre daha başarılı olması ve böylece daha iyi bir kapalılığa ulaşmış olması gösterilebilir çünkü ormanda ve orman toprağında yaşayan hayvanların ve bitkilerin artıkları da bu organik maddeye katılırlar ve bu atıklar toprağın yüzeyinde bir ölü örtü halinde serilmiş durumdadır. Bu ölü örtünün ayrışması, ayrışma ürünleri veya humus halinde toprağa karışması toprağın fiziksel ve kimyasal özellikleri üzerinde olduğu kadar bitkilerin beslenmesi ve büyümesi üzerinde de önemli etkiler yapar (Balzı 1996; Kantarc1 2000).

Benzer şekilde Artvin Çoruh Havzası Deriner Barajı yol şevi ve geçici yerleşim yeri çevre ağaçlandırılmasında kullanılan farklı türlerin altındaki toprakların bazı özelliklerinin doğal ve açık alanların toprak özellikleriyle karşılaştırılması ile ilgili bir çalışmada açık alanlarla karşılaştırıldığında, ağaçlandırma yapılan alanların topraklarında yüksek miktarda organik madde miktarı bulunduğu belirtilmiştir (Sarıyıldız 2008).

Toplam Azot: Araştırma sahasından alınan toprak örneklerinin analizi sonucunda azot miktarı en fazla orman bloğundaki topraklarda, daha sonra yalancı akasya ve sarıçam bloğundaki terasların topraklarında görülmüştür. Bunun nedeni olarak orman bloğundaki topraklarda bulunan mikroorganizma faaliyetlerinin fazla ve hızlı olması gösterilebilir. Ölü örtü bakımından zengin olan orman toprağının ayrışması sonucu azot miktarında da artışın olduğu düşünülmektedir. Ayrıca ölü örtü materyalinin cinsi ve ayrışma süresinin de bunda etkili olduğu düşünülmektedir. Bununla beraber, yalancı akasya ile sarıçam terasları arasındaki azot miktarı farkı ise yalancı akasyanın azot bağlayıcı özelliğinden kaynaklandığı düşünülmektedir. Bilindiği üzere ağaç köklerinde ortak yaşayan yumru (Rhizobium) bakterileri ve mantarlar toprak havasındaki serbest azotu bağlamaktadırlar. Bunlar arasında kızılağaç köklerindeki Actinomyces alni mantarı ile iğde köklerindeki Actinomyces elaeagni mantarı ve akasyalarla (Kıbrıs Akasyası dâhil), Yalancı Akasya (Salkım ağacı = Robinia pseudoacacia) köklerindeki yumrulu bakteriler sayılabilir (Kantarc1 2000).

Benzer şekilde Gümüşhane ili Torul ilçesi yalancı akasya ağaçlandırmalarının biyokütle ve bazı toprak özellikleri yönünden incelendiği çalışmada (Tüfekçioğlu vd. 2002), yalancı akasya kökleri ile ortak yaşayan Rhizobium sp. 
bakterileri sayesinde havanın serbest azotunu bağladığını ve bu şekilde toprağı azotça zenginleştirdiğini, toprağa kazandırılan azotun 75 ile $200 \mathrm{~kg} / \mathrm{ha}$ arasında değişebildiği belirtilmektedir.

Elektrik İletkenliği (Tuzluluk): Araştırma sahasından alınan toprak örneklerinin analizi sonucunda elektrik iletkenliğinin en fazla orman bloğundaki topraklarda, daha sonra yalancı akasya ve sarıçam bloğundaki terasların topraklarında görülmüştür. Bunun nedeni olarak buralarda biriken ölü örtü ve organik maddeye bağlı olarak ayrışma sonucu serbest kalan besin maddeleri ile ilişkili olduğu düşünülmektedir. Benzer şekilde Turan Emeksiz Kıyı Kumul Ağaçlandırmasının Bazı Toprak Özellikleri Üzerine Etkisinin araştırıldığı çalışmada (Atmaca ve Yılmaz 2006), kontrol parsellerinde ve zayıf kapalı okaliptus parsellerindeki tuzluluk değerlerinin kapalılığı yüksek diğer parsellerden daha düşük olduğunu belirtmektedir.

\section{Sonuç ve Öneriler}

$\mathrm{Bu}$ çalışma ile varmak istediğimiz hedeflerden biri yalancı akasya ve sarıçam fidanları kullanılarak yapılan erozyon kontrol ve ağaçlandırma çalışmalarının yol inşaatları sonucunda tahrip edilen arazilerdeki toprak özelliklerini iyileştirip iyileştirmediği sorusuna cevap bulmaktı. Bu amaçla, yalancı akasya ve sarıçam fidanları kullanılarak dikim yapılan iki farklı erozyon kontrol çalışma sahasından oluşan parseller ile müdahale görmemiş doğal orman sahası (kontrol) bazı toprak özellikleri bakımından karşılaştırılmıştır. Bulgular bölümünde de belirtildiği üzere analizler göstermiştir ki bu iki saha ile doğal orman örtüsüne sahip saha arasında $\%$ kum, \% toz ve \% kil içeriklerinde, $\mathrm{pH}$, toplam kireç, organik madde, toplam azot ve elektrik iletkenliği değerleri bakımından istatistiksel anlamda fark bulunmuştur. Orman parselindeki toprakların kum, kil, toz, organik madde, toplam azot ve elektrik iletkenliği gibi toprak özellikleri yalancı akasya ve sarıçam parselindeki toprak özelliklerine oranla yüksek çıkmıştır. Ancak orman parselindeki toprakların pH ve kireç gibi toprak özellikleri yalancı akasya ve sarıçam parselindeki toprak özeliklerine göre düşük çıkmıştır.

Yalancı akasya ile sarıçam blokları arasında hem yetişme hem de alanın kapalılığının sağlanması açısından bir karşılaştırma yapıldığında yalancı akasya parselinin sarıçamdan çok daha iyi bir gelişim gösterdiği gözlemlenmiştir. Yetişmedeki bu fark yalancı akasya parselinde çok daha iyi bir kapalılığın oluşmasına da neden olmuştur. Bu durum toprak özellikleri üzerinde de olumlu etkilerde bulunmuş ve genel anlamda bir karşılaştırma yapıldığında yalancı akasya parselinde sarıçam parseline göre daha fazla organik madde ve toplam azot oluştuğu görülmektedir.

Sonuç olarak, tahrip edilen alanlarda yapılan erozyon kontrol ve ağaçlandırma çalışmaları üzerinden 7 yıl geçmesine rağmen bozulan alanlardaki toprak özelliklerinin istatiksel anlamda önemli bir iyileşme göstermediği ve tahrip edilmemiş orman örtüsü altındaki toprak özellikleri değerlerinden hala uzak olduğu ortaya konulmuştur. Bu da, bize, büyük çaplı proje veya yatırımlar yaparken öncelikli ilkenin doğal kaynaklara en az zarar verilmesi olduğunu tekrar hatırlatmaktadır. Çalışma alanımızda inşa edilen yol uygun tekniklerle yapılmış olsaydı ve özellikle de ortaya çıkan kazı malzemesi depo edilmiş olsaydı hem doğal bitki örtüsü ve toprak korunmuş olacak hem de bu tahribata karşı yapılan zor ve masraflı önlem yöntemlerine gerek duyulmayacaktı.

\section{Teşekkür}

$\mathrm{Bu}$ araştırmada alınan toprak örnekleri üzerindeki bazı analizlerin yapılmasında bize laboratuvar kullanma desteği veren Eskişehir Orman, Toprak ve Ekoloji Araştırmaları Enstitüsü Müdürlüğü’ne ve bu kurumda başmühendis olarak görev yapan Dr. Nejat Çelik'e teşekkürlerimizi sunarız. Ayrıca, bu çalışmanın tamamlanmasında maddi açıdan destek veren TEMA Vakfı'na ve özellikle Eğitim Uzmanı Gökçen HAZEN'e de sağladıkları yardımdan dolayı teşekkürlerimizi sunariz.

\section{Kaynaklar}

Anşin R., (1983), Türkiye'nin flora bölgeleri ve bu bölgelerde yayılan asal vejetasyon tipleri, KTÜ Orman Fakültesi Dergisi, 6(2), 318-339.

Atay İ., (1985), Akasya (Robinia pseudoacacia L.)'nın önemi ve silvikültürel özellikleri, İstanbul Üniversitesi Orman Fakültesi Dergisi, 35(1), 22-31.

Atmaca F., Yılmaz K.T., (2006), Turan emeksiz kıyı kumul ă̆açlandırmasının bazı toprak özellikleri üzerine etkisi, Doğu Akdeniz Ormancılık Araştırma Müdürlüğü DOA Dergisi, 12, 207-226.

Atmiș E., Özden S., Lise W., (2007), Urbanization pressures on the natural forests in turkey: an overview, Urban Forestry \& Urban Greening, 6(2), 83-92.

Balcı A.N., (1996), Toprak koruması, İ.Ü. Orman Fakültesi Yayınları, Yayın No 439, ss490.

Cerda A., Lasanta T., (2005), Long-term erosional responses after fire in the Central Spanish Pyrenees: 1. Water and sediment yield, Catena, 60(1), 59-80.

Cerda A., (2007), Soil water erosion on road embankments in eastern Spain, Science of the Total Environment, 378(1-2), 151-155.

de La Paix M.J., LanhaI L., Xi C., Ahmed S., Varenyam A., (2013), Soil degradation and altered flood risk as a consequence of deforestation, Land Degradation Development, 24(5), 478-485.

Dehşet F., (2011), Baraj ve yol inşası nedeniyle tahrip edilen alanlarda yapılan erozyon kontrol çalışmalarının toprak özelliklerinin iyileştirilmesi üzerine etkilerinin irdelenmesi, Yüksek Lisans Tezi, Artvin Çoruh Üniversitesi, Artvin. 
DSI,, (2007), Devlet Su İşleri Genel Müdürlüğ̈̈ 2007 Yılı Faaliyet Raporu, http://www.dsi.gov.tr/docs/stratejik-plan/dsı-2007faaliyet-raporu.pdf, [Erişim 20 Mart 2008].

Eruz E., (1979), Toprak tuzluluğu ve bitkiler üzerindeki genel etkileri, İ.Ü. Orman Fakültesi Dergisi, B Serisi, 29(2), 112-120.

Gattinger T.E., (1962), Explonatory text of geological map of Turkey, MTA Publications, Ankara.

Giray N., (1994), Sarıçam el kitabı, Ormancılık Araştırma Enstitüsü, Muhtelif Yayınlar Serisi, 67, Ankara, 285ss.

Gülçur F., (1974), Toprağın fiziksel ve kimyasal analiz metodları, İ.Ü. Orman Fakültesi Yayınları, İ.Ü. Yayın No: 1970, O. F. Yayın No: 201, Kutulmuş Matbaası, İstanbul.

Hanson D.A., Britney E.M., Earle C.J., Stewart T.G., (2013), Adapting habitat equivalency analysis (HEA) to assess environmental loss and compensatory restoration following severe forest fires, Forest Ecology and Management, 294, 166-177.

Irmak A., (1954), Arazide ve laboratuvarda topră̆ın araştırılması metodları, İ.Ü. Orman Fakültesi Yayınları, İ.Ü. Yayın No: 599, O. F. Yayın No: 27, Halk Matbaas1, İstanbul, 150ss.

Kacar B., (1996), Toprak analizleri (bitki ve toprağın kimyasal analizleri III), Ankara Üniversitesi Ziraat Fakültesi Eğitim, Araştırma ve Geliştirme Vakfı Yayınları, No: 3, Ankara, 705ss.

Kantarcı M.D., (2000), Toprak ilmi, İ.Ü. Orman Fakültesi Yayınları, İ.Ü. Yayın No:4261, Orman Fak. Yayın No: 462, Çantay Basımevi, İstanbul.

Karagül R., (1994), Trabzon-Söğütlüdere havzasında farklı arazi kullanım şartları altındaki toprakların bazı özellikleri ile erozyon eğilimlerinin araştırılması, Doktora Tezi, Karadeniz Teknik Üniversitesi, Trabzon.

Ketin İ., (1949), Artvin bölgesinin jeolojik etüdü hakkında memuar, MTA Enstitü Yayınları, Ankara.

Ketin İ., (1954), Artvin bölgesinin jeolojik etüdü hakkında memuar, MTA Rapor No: 1951, Ankara.

Kızmaz M., (1998), Macaristan'da yalancı akasya yetiştiriciliği ve Türkiye'de yetişme imkanlarl, Hızlı Gelişen Türlerle Yapılan Ağaçlandırma Çalışmalarının Değerlendirilmesi ve Yapılacak Çalışmalar, OGM Toplantısı, 8-9 Aralık, Ankara, ss. 295-303.

Martin A., Diaz-Ravina M., Carballas T., (2012), Short- and medium-term evolution of soil properties in Atlantic forest ecosystems affected by wildfires, Land Degradation Development, 23(5), 427-439.

Özalp M., Yavuz A., Yüksek T., Toker E., (2009), Baraj ve yol yapımlarının doğal kaynaklara etkisi: Aşağı Çoruh Havzası örneği, II. Ulusal Baraj Güvenliği Sempozyumu, 13-15 Mayıs, Eskişehir.

Özhan S., (2004), Havza amenajmanı, İ.Ü. Orman Fakültesi, Havza Yönetimi Anabilim Dalı, Orman Fakültesi Yayın No: 481, İstanbul, 384ss.

Rigueiro-Rodriguez A., Mosquera-Losada M.R., Fernández-Núñez E., (2012), Afforestation of agricultural land with Pinus radiata D. don and Betula alba L. in NW Spain: effects on soil PH, understorey production and floristic diversity eleven years after establishment, Land Degradation Development, 23(3), 227-241.

Rudel T.K., Schneider L., Uriarte M., (2010), Forest transitions: an introduction, Land Use Policy, 27, 95-97.

Saraç M., Eciroğlu O., (2008), Çoruh Havzası ve EİE, Su ve Enerji Konferansı, 25-26 Eylül, Artvin.

Sarıyıldız T., Duman A., (2008), Çoruh havzası Deriner barajı yol şevi ve geçici yerleşim yeri çevre ağaçlandırılmasında kullanılan farklı türlerin altındaki toprakların bazı özelliklerinin doğal ve açık alanların toprak özellikleriyle karşılaştırılması, Baraj Havzalarında Ormancılık I. Ulusal Sempozyumu Bildiriler Kitabı'nın içinde, 29-30 Nisan, Kahramanmaraş Sütçü İmam Üniversitesi, Kahramanmaraş, ss. 275-287.

Sever R., (2005), Çoruh havzası enerji yatırım projeleri ve çevresel etkileri: coğrafi açıdan bir araştırma, Çizgi Kitapevi, 1. Baskı, 280 ss.

Toker E., (2010), Borçka ve Deriner barajlarının Çoruh havzasında neden olduğu arazi kullanım değişiminin ve arazi tahribatının irdelenmesi, Yüksek Lisans Tezi, Artvin Çoruh Üniversitesi, Artvin.

TSGM, (1984), Çoruh Havzası Toprakları, Toprak-Su Genel Müdürlüğü, Yayın No: 756, Havza No: 23, Raporlar Serisi: 94, Ankara.

Tüfekçioğlu A., Güner S., (2008), Artvin-Murgul Yalancı Akasya (Robinia pseudeoacacia L.) ağaçlandırmalarının odun üretimi, biyokütle, karbon depolama, toprak ıslahı ve erozyon önleme yönlerinden araştırılması, TÜBİTAK-TOVAG 1001 Proje No: 1060418, Artvin.

Tüfekçioğlu A., Yüksek T., Kalay H.Z., (2002), Gümüşhane ili Torul ilçesi yalancı akasya ağaçlandırmalarının biyokütle ve bazı toprak özellikleri yönünden incelenmesi, Gümüşhane ve Yöresinin Kalkınması Sempozyumu, 23-25 Ekim, Gümüşhane.

URL-1, (2011), Artvin İl Gelişme Planı (AGEP), T.C. Artvin Valiliği, http://www.artvin.gov.tr/userfiles/files/aigp_raporu.pdf, [Erişim 14 Mayıs 2011].

Ürgenç S., (1998), Ağaçlandırma tekniği, İ.Ü. Orman Fakültesi Yayınları, İ.Ü. Yayın No: 3994, O.F. Yayın No:441, İstanbul, 600ss.

WCD, (2000), Dams and Development. A New Framework for Decision-Making, The Report of the World Commission on Dams, Earthscan Publications Ltd, London and Sterling, VA, USA.

Yaltırık F., (1991), Yalancı Akasya'yı (Robinia pseudoacacia L.) gereğince tanımıyoruz, Orman Mühendisliği Dergisi, 9, 4-7.

Yaltırık F., (1993), Dendroloji Ders Kitabı, Gymnospermae (Açık Tohumlular), İ.Ü. Orman Fakültesi Yayınları, İ.Ü. Yayın No: 3443, O.F. Yayın No:386, 2. Bask1, İstanbul, 320ss.

Yıldırımer S., Özalp M., Erdoğan Yüksel E., (2015), Büyük baraj projeleri ve bağlantıl yol inşaatlarl sonucunda Çoruh Nehri Havzasında oluşan arazi kayıplarının ve tahribatlarının belirlenmesi, Artvin Çoruh Üniversitesi Orman Fakültesi Dergisi, 16(1), $1-17$.

Yüksek F., Küçük M., Erdoğan Yüksel E., Güner S., (2010), Artvin merkez Seyitler köyünde erozyon kontrol amaçlı yapılan ăgaçlandırma çalışmasının bazı toprak özelliklerine etkisi, III. Ulusal Karadeniz Ormancılık Kongresi Bildiriler Kitabı'nın içinde, Artvin, ss.973-980.

Yüksek T., Ölmez Z., (2002), Artvin Yöresinin İklim, Toprak Yapısl, Orman Alanları, Ağaç Serveti ve Ormancılık Çalışmalarıyla Illgili Genel Bir Değerlendirme, Artvin Çoruh Üniversitesi Orman Fakültesi Dergisi, 3(1), 50-62.

Zapata V.M., Robledano F., (2014), Assessing biodiversity and conservation value of forest patches secondarily fragmented by urbanisation in semiarid southeastern Spain, Journal for Nature Conservation, 22(2), 166-175. 